\title{
Extract of haruan (channa striata) extract increasing reepithelialization count in wound healing process on wistar rat's buccal mucosa
}

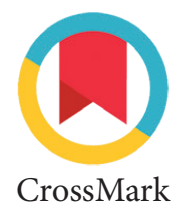

\author{
Devintha AM. Tamales, ${ }^{1 *}$ Nurdiana Dewi, ${ }^{1}$ Lena Rosida ${ }^{2}$
}

\section{Abstract}

Objective: Haruan is Kalimantan's indigenous fish which has the potency to accelerate wound healing. Haruan extract has substantial properties such as albumin, Zn, Cu and Fe to accelerate wound healing. The aim of this study was to examine the effect of haruan extract on reepithelialization of wistar rat's buccal mucosa wound healing.

Material and Methods: Galur wistar rats were chosen as population and samples were taken with these requirements: male, weight of 200-250 g, age of 2-2.5 months, activemovement and healthy. Samples were randomly divided into 16 treatment groups. Each group had 8 male rats, which then got divided into
4 smaller groups of 2 rat's each. The smaller groups were given different treatments of 25\%,50\%, 100\% haruan extract and aquadest as control.

Results: Epithelial thickness count reached its peak on day 10. Mean epithelial thickness scoring of each group was $50.40 \mu \mathrm{m}, 56.85 \mu \mathrm{m}$, $62.81 \mu \mathrm{m}, 38.28 \mu \mathrm{m}$ respectively. Two-way Anova and Post-HocLSD tests presentedasignificant difference between negative control and haruan extract groups.

Conclusion: Haruan extract treatment significantly increases epithelial thickness count in wound healing process.
${ }^{1}$ Department of Oral Biology, Dentistry Program Study, University of Lambung Mangkurat, Banjarmasin, Indonesia ${ }^{2}$ Department of Pathology, Faculty of Medicine, University of Lambung Mangkurat, Banjarmasin, Indonesia
*Correspondence to: Devintha Ayu Mellyana Tamales, Department of Oral Biology, Dentistry Program Study, University of Lambung Mangkurat, Banjarmasin, Indonesia devintha06@gmail.com

\section{Received: 31 March 2015}

Revised: 25 April 2016

Accepted: 26 April 2016

Available Online: 30 April 2016

Keywords: Haruan extract, Wound healing, Epithelial thickness, Histopathology

Cite This Article: Tamales DAM, Dewi N, Rosida L. 2016. Extract of haruan (channa striata) extract increasing reepithelialization count in wound healing process on Wistar Rat's Buccal Mucosa. Journal of Dentomaxillofacial Science 1(1): 12-15. D01: 10.15562/jdmfs.v1i1.17

\section{Introduction}

Oral mucosa is the soft tissue layering the surface of oral cavity where injury can occur inevitably. A number of treatments, such as dental ones often inflict wounds on oral mucosa. ${ }^{1}$ Wound will be resolved through healing or repair, a complex process involving a lot of cells. ${ }^{2}$ Biologic process of wound healing is generally divided into a number of phases tightly associated with each other: inflammation, proliferation and remodeling. Inflammation is the initial phase of wound healing. After wound has been thoroughly cleaned from necrotic tissues and leftover debris, then proliferation phase starts from day 3 to day $5 .{ }^{3,4}$

Proliferation is marked with granulation tissues formation in wound: in this phase, macrophage and lymphocyte play their roles as predominant cells undergoing proliferation and migration, alongside epithelial, fibroblast and endothelial cells. This process accounts heavily on metabolic factor, oxygen concentration and growth factors. Proliferation phase starts 3 days after injury. The epithelialization takes place a few hours after wound occurs. ${ }^{5}$

Reepithelialization is a wound repair stage including mobilization, migration, mitosis and epithelial cells differentiation. These stages will restore the loss-of-skin integrity. Epithelial cells mitosis and migration have key roles in this function. At initial phase, reepithelialization will occur as epithelial cells movement from free tissues' edge to the destructed tissues. Epithelial cells proliferation starts due to epithelial cells mitotic activity on the wound's edge. While proliferating, a number of mature epithelial cells skim out from wound's edge with amoeboid movement to wound's surface on dermis. This stage causes migrated epithelial cells to merge in the wound's center, until the wound is fully closed and free from external contamination, thus the maturation process under this layer will proceed better. A wound is fully healed when the area where it occurs already undergoes complete epithelialization and does not acquire anymore treatment. ${ }^{6}$

The studies show that fish consumption can promote wound healing. Gabus fish (channa sp) is a kind of fishes commonly consumed by Indonesian people, especially in Kalimantan where this kind lives in their native habitat. Haruan (channa striata) is a sub-kind of gabus that is dearly loved as daily meals. Apart from its distinguished taste, eating this fish is widely known to help promote wound healing because of its high protein, around $25.2 \%$ and albumin, a component 
other fishes, such as catfish, gurami, nila, gold fish and others, do not have. Haruan has high albumin in which it contains around $62.24 \mathrm{~g} / \mathrm{kg}$ (6.22\%). Albumin's role in wound healing includes transporting small molecules through cells' plasma and fluid and supporting osmotic pressure in capillaries, among other roles such as platelet formation inhibitor and anti-thrombocytes, antioxidants and cells permeability. Furthermore, haruan also has essential and non-essential amino acid content and has better quality compared to albumin coming from eggs. ${ }^{7,8}$

Haruan extract contains prominent substances in promoting wound healing such as $\mathrm{Zn}, \mathrm{Cu}$ and $\mathrm{Fe}$. $\mathrm{Zn}$ has an important role in gene regulation, keeping biologic cellular membrane and skin structure integrity, which consist of connective tissues composed of proteins, in check. $\mathrm{Cu}$ is thought as a component related to $\mathrm{Fe}$ because of its similar characteristic and role. Cu functions in maintaining myelin sheath integrity, bone and connective tissue formation and melanin pigment formation in skin and hair. Fe is associated with haemoglobin in red blood cells, transferrin and ferritin. ${ }^{9-12}$

This study aimed to examine the effect of haruan extract (channa striata) and to measure epithelial width on reepithelialization in wistar rats' buccal mucosa wound healing after haruan extract was applied.

\section{Material and Methods}

In this pure experimental study using posttest-only with control group design, extract was made in Math and Sciences, Faculty of Lambung Mangkurat University, Banjarbaru and treatments on animals and histologic preparation were performed at Balai Veteriner, Banjarbaru. This study passed the ethical check by Medical Research Ethic Committee of Lambung Mangkurat University, Banjarmasin as stated in the letter No.071/KEPK-FK UNLAM/EC/ $\mathrm{VI} / 2014$.

Galur wistar rats were chosen as population and samples were taken with these requirements: male, weight of 200-250 g, age of 2-2.5 months, active movement and healthy. Samples were randomly divided into 16 treatment groups. Each group had 8 male rats, which then got divided into 4 smaller groups of 2 rats each. The smaller groups were given different treatments of $25 \%, 50 \%, 100 \%$ haruan extract and aquadest as control.

Fresh haruan were hand-picked weighing around $500-1000 \mathrm{~g}$ to control the extract quality. Fishes were cleaned from their scales and the abdominal contents were cut out. The meats were sliced into small pieces using transversal cut and the bones were taken out.
Fresh haruan extract was processed through steaming using aquadest and haruan in 1:1 proportion. Aquadest was put first into steaming pot then sieve was put over it. Haruan was placed on the sieve and steamed in $70^{\circ} \mathrm{C}$, using medium fire for 50 minutes until yellowish liquid was retrieved. The liquid was put in rotary instrument for 5 hours to isolate the extract from aquadest until a yellowish thick extract was produced, it was then filtered from debris and placed in a closed container. $25 \%$ extract was made by mixing $0.75 \mathrm{~mL} 100 \%$ haruan extract with $2.25 \mathrm{~mL}$ aquadest, $50 \%$ extract was made by mixing $1.5 \mathrm{~mL} 100 \%$ haruan extract with $1.5 \mathrm{~mL}$ aquadest and $100 \%$ extract was made without any mixing.

Before treatments, rats were left alone to adapt in laboratory environment for a week, then they were divided into 16 groups. Diethyl ether was given through inhalation until the rats were sedated. Sharp cut of $10 \mathrm{~mm}$ long and $1 \mathrm{~mm}$ deep was made on rat's buccal mucosa using sterile scalpel and blade: blood was cleaned using aquadest and sterile cotton bud. Groups 1, 2, 3 and 4 as negative control groups were given $2.5 \mathrm{~mL} /$ $250 \mathrm{~g}$ weight aquadest orally once a day. Groups $5,6,7$ and 8 as $25 \%$ haruan extract treatment groups were given $2.5 \mathrm{~mL} / 250 \mathrm{~g}$ weight $25 \%$ haruan extract orallyonce a day. Groups 9, 10, 11 and 12 as $50 \%$ haruan extract treatment groups were given $2.5 \mathrm{~mL} / 250 \mathrm{~g}$ weight $50 \%$ haruan extract orally once a day. Group 13, 14,15 and 16 as $100 \%$ haruan extract treatment groups were given $2.5 \mathrm{~mL} / 250$ g weight $100 \%$ haruan extract orally once a day. Aquadestand haruan extract were applied using half-moonsonde once a day until day 10.

Rats were anesthetized using diethyl ether and decapitated on day 3, 5, 7 and 10. Each rat's buccal mucosa on post-incision area was cut $\pm 5 \mathrm{~mm}$ wide and fixated in $10 \%$ Buffer Neutral Formalin (BNF) solution, then followed by a histologic procedure to make paraffin block. To make a sample preparation, paraffin block was cut $5 \mathrm{~mm}$ wide and stained using Hematoxylin and Eosin (HE). Examinationas performed using light microscope, connected to a computer. Epithelial width was measured using software image.

\section{Results}

Average width of reepithelialisation of $25 \%, 50 \%$, and $100 \%$ haruan extract groups and negative control groups (aquadest) on day 3 to day 10 can be seen on figure 1.

Epithelial width rose on day 3 in negative control 25\%, 50\% and 100\% haruan extract 


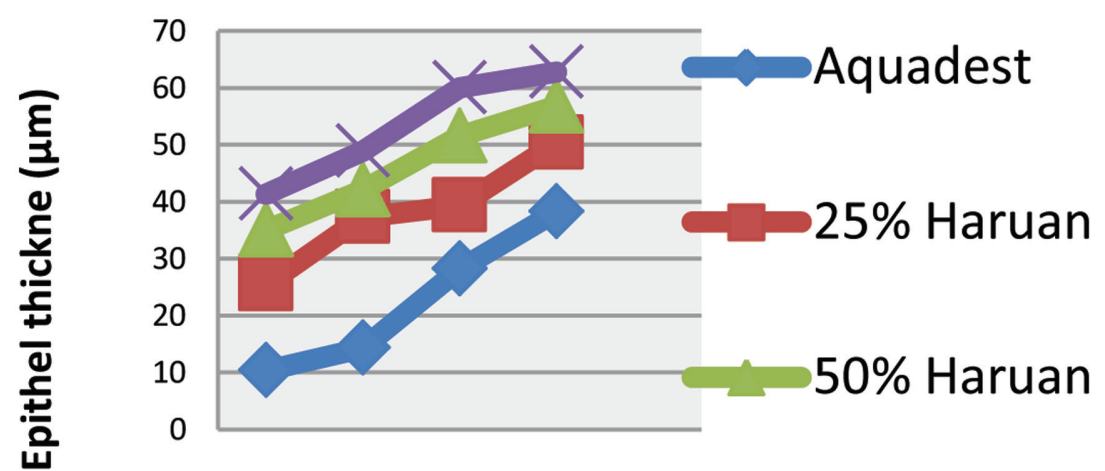

Day Day Day Day

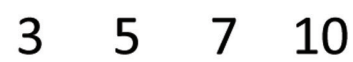

Days

Figure 1 Treatment comparison graphic
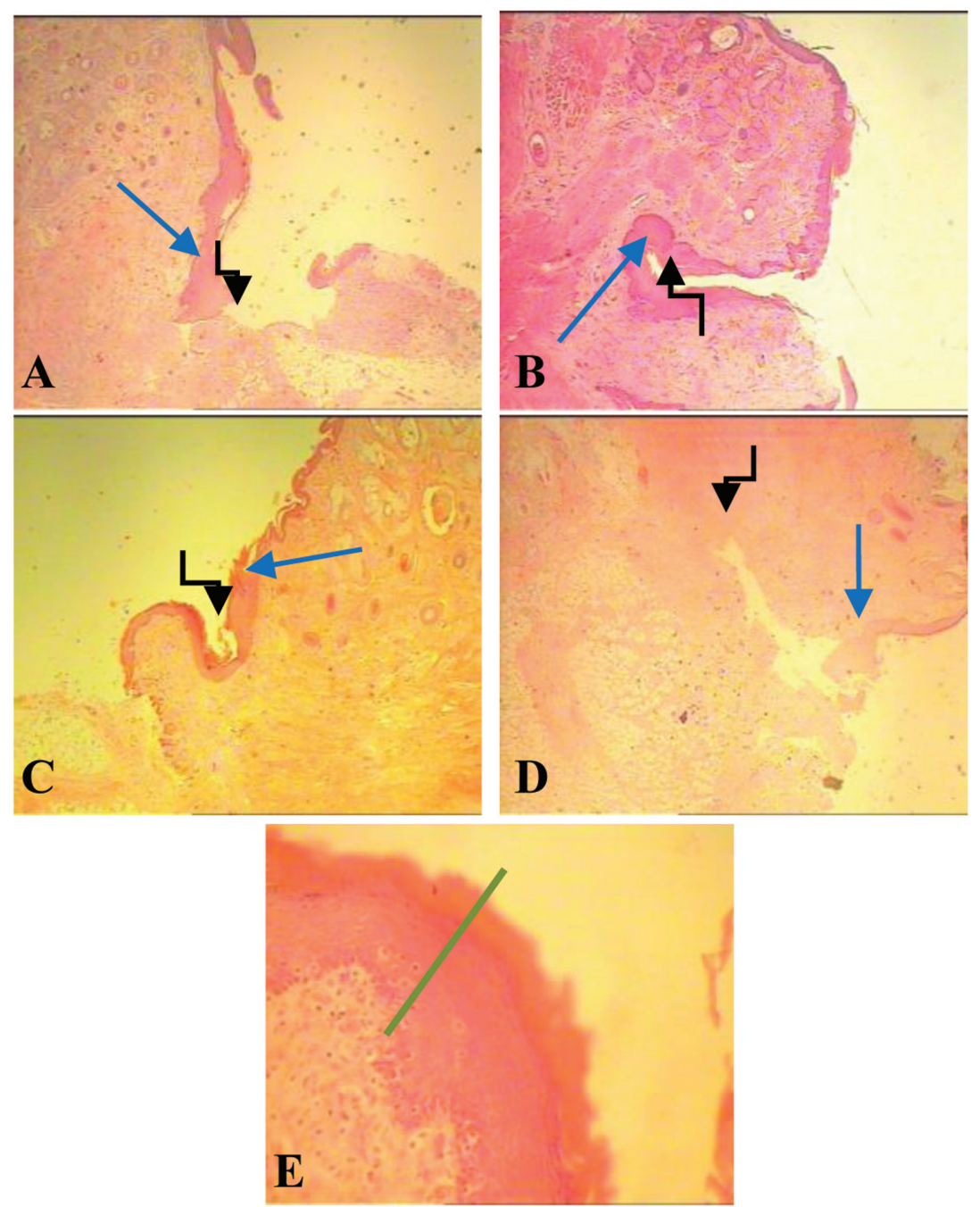

Figure 2 Histopathological feature reepithelization on day 10 (40x): A. 25\% haruan fish extract, B. 50\% haruan fish extract, C. $100 \%$ haruan fish extract, D. Negative control, E. Histopathological feature reepithelization process (400x). Black arrow show marginal wound, blue arrow show epithelium, line show epithelial thickness treatment groups while the peak of epithelial width was on day 10 in all groups.

Study results were then analyzed using ShapiroWilk normality test with samples less than 50 . In day-3, 5, 7 and 10 groups, data was normally distributed with p-value of $0.261,0.284,0.874$ and 0.728 respectively. In treatment groups of aquadest $25 \%$, $50 \%$ and $100 \%$ haruan extract, data was normally distributed with p-value of $0.999,0.584,0.083$ and 0.792 respectively.

Levene's test of variance homogeneity showed that day groups had significance value of 0.608 ( $p>0.05)$ while treatment groups had significance value of 0.866 ( $p>0.05)$. These results showed that epithelial width measurement had homogenous variance.

Parametric test of one way Anova was then performed, the results obtained showed significant difference according to days with p-value of $0.000(\mathrm{p}<0.05)$ and according to treatments of $0.000(p<0.05)$. Data analysis was followed by post-hoc LSD test, day groups' results showed that there was a significant difference among day 3, 5, 7 and 10 groups. Constant significance was found in day 10 group $(\mathrm{p}<0.05)$ with the highest mean count of 24.08 figure 2 .

\section{Discussion}

This study proved that mean epithelial width of treatment groups was higher compared to negative control. Epithelial width enhancement was prominent in 50\% and $100 \%$ haruan extract groups. $25 \%$ haruan extract groups also showed epithelial width improvement but the count was thinner compared to $50 \%$ and $100 \%$ haruan extract groups. This result was possibly influenced by the higher content of substances in $50 \%$ and $100 \%$ haruan extract groups, thus the nutrition needed during wound healing was more than adequate. Haruan extract has substantial substances for tissue synthesis and wound healing, such as $\mathrm{Zn}, \mathrm{Cu}$ and $\mathrm{Fe}$. A previous study by Sura proved that $100 \%$ haruan extract applied orally could help rats back skin wound healing. ${ }^{13}$ Haruan extract was thoroughly concentrated in this study using steaming thus the active substances were higher in concentration. According to Jannata et al. ${ }^{14}$ a higher concentration means higher active substances in an extract. ${ }^{14}$

Reepithelialization is a repair process of skin epithelial cells to promote the closing of wound. A faster reepithelialization can support and improve epidermal structure and skin. Reepithelialization involves mobilization, migration and mitosis and epithelial cells differentiation. These stages restore the loss-of-skin integrity. Epithelial cells mitosis and migration play important roles in these stages. 
Reepithelialization starts when epithelial cells move from free tissue's end to destructed tissues. ${ }^{15}$

Studies on haruan extract's by Santoso ${ }^{8}$ stated that haruan extract contained substantial substances for tissues synthesis and wound healing, such as protein $(3.36 \mathrm{~g} / 100 \mathrm{~mL})$, albumin $(2.17 \mathrm{~g} / 100 \mathrm{~mL}), \mathrm{Zn}(3.43 \mathrm{mg} / 100 \mathrm{~mL}), \mathrm{Cu}(2.34$ $\mathrm{mg} / 100 \mathrm{~mL})$ and $\mathrm{Fe}(0.81 \mathrm{mg} / 100 \mathrm{~mL}){ }^{8}$ Main roles of albumin are transporting small molecules through cells plasma, fluid and supporting osmotic pressure in capillaries, among other roles such as platelet formation inhibitor, anti-thrombocytes, cells permeability and antioxidant. $\mathrm{Zn}$ is needed in gene regulation, keeping biologic cell membrane and skin structure integrity, which consist of connective tissues composed of proteins, in check. $\mathrm{Cu}$ is thought as a component related to $\mathrm{Fe}$ because it has similar characteristic and role. $\mathrm{Cu}$ plays a role in supporting myelin sheath integrity, bone and connective tissue formation, melanin pigment formation in skin and hair. Fe is associated with haemoglobin in red blood cells, transferrin and ferritin. The main role of $\mathrm{Fe}$ is body oxidation, thus $\mathrm{Fe}$ availability will determine metabolic activity. ${ }^{9-12}$ 50\% haruan extract application was considered more optimal to promote wound healing, because in this study a few samples failed to survive after $100 \%$ haruan extract was given. A toxicity test is needed to confirm the safety of $100 \%$ haruan extract application.

\section{Conclusion}

In conclusion, there is an effect of $25 \%, 50 \%$ and $100 \%$ haruan (channa striata) extract on wistar rat's buccal mucosa wound healing. 50\% and 100\% haruan extract are more effective to improve epithelial width.

\section{Conflict of Interest}

The authors report no conflict of interest.

\section{References}

1. Ismardianita E, Soebijanto, Sutrisno. Pengaruh kuretase terhadap penyembuhan luka pasca pencabutan gigi dan kajian histologis pada tikus galur wistar. Dentika Dent J 2003;8: 75-80.

2. Pusponegoro AD. Luka. In Sjamsuhidajat R, De-Jong W. Editors. 2nd ed. Jakarta: EGC; 2005.

3. Mercandetti M, Cohen A. Wound healing and repair. E Medicine (cited 2002 Oct 7). Available from URL: http:// www.eMedicine.com.Inc

4. Collagen and the wound healing process. Available from: URL: http://www.woundheal.com

5. Handayani I. Aktivitas sediaan gel dari ekstrak lidah buaya (aloe barbadensis miller) untuk proses persembuhan luka pada mencit (mus musculus). Bogor: Fakultas Kedokteran Hewan Institut Pertanian Bogor; 2006.

6. Suprayitno E, Chamidah A, Carvallo. Albumin ikan gabus (Ophiocephalus striatus) sebagai makanan fungsional mengatasi permasalahan gizi masa depan. Pidato Pengukuhan Jabatan Guru Besar; 2008.

7. Piliang WG, Soewondo. Fisiologi nutrisi. Bogor: IPB press; 2006. p. 2.

8. Santoso AH. Uji potensi ikan haruan (Channa striata) sebagai hepatoprotektor pada tikus yang diinduksi parasetamol. Bogor: IPB; 2009.

9. Sunatrio S. Peran albumin pada penyakit kritis, dalam konsensus pembuatan albumin pada sirosis hati. Jakarta: FKUI press; 2003.

10. Baird SK, Kurz T, Brunk T. Metallothionein protects againts oxidative stress induced lysosomal destabilization. Biochem J 2006;15: 275-283.

11. Sulistiawati, Nuraini IDA. Pemberian ekstrak daun lidah buaya (Aloe vera) kosentrasi $75 \%$ lebih menurunkan jumlah makrofag dari pada kosentrasi 50\% dan 25\% pada radang mukosa mulut tikus putih jantan. Denpasar: Program Pasca Sarjana Ilmu Biomedik Universitas Udayana; 2011.

12. Navia JM. Animal models in dental research. In Alabama School of Dentistry. Alabama: The University of Alabama Press; 1997. p. 79.

13. Sura GM. Efektivitas ekstrak ikan haruan (Channa striata) $100 \%$ pada proses penyembuhan luka kulit punggung mencit (Mus musculus) secara gambaran histopatologi. Program Studi Kedokteran Gigi FK Unlam Banjarmasin; 2014. p. 21

14. Jannata RH, Gunadi A, Ermawati E. Daya antibakteri ekstrak kulit apel manalagi (Malus sylvestris mill.) terhadap pertumbuhan streptococcus mutans. E-Jurnal Pustaka Kesehatan 2014; 2: 26-27.

15. Soepribadi I. Regenerasi dan penyembuhan untuk kedokteran gigi. Jakarta: Sagung Seto; 2013.

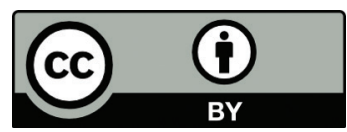

This work is licensed under a Creative Commons Attribution 